STUDIA PRAWNO-EKONOMICZNE, T. CXV, 2020

PL ISSN 0081-6841; e-ISSN 2450-8179 $\quad$ s. 371-387

https://doi.org/10.26485/SPE/2020/115/20

\title{
Dagmara SKURPEL*
}

iD https://orcid.org/0000-0002-9631-0147

\section{REGULACJE PRAWNE W KONTEKŚCIE OBSŁUGI KLIENTÓW W E-HANDLU Z PERSPEKTYWY KONSUMENTÓW I PODMIOTÓW RYNKOWYCH}

\begin{abstract}
Abstrakt
Przedmiot badań: Ze względu na dynamiczny rozwój i charakterystykę branży e-commerce ważny element $\mathrm{w}$ jej prawidłowym funkcjonowaniu stanowią regulacje prawne mające na celu z jednej strony umożliwienie prawidłowego funkcjonowania przedsiębiorców prowadzących tego typu działalność gospodarczą, z drugiej strony ich zadaniem jest ochrona interesów osób, które korzystają z usług branży e-commerce, czyli w szczególności konsumentów. W niniejszym artykule przedstawiono najważniejsze akty prawne regulujące funkcjonowanie handlu w sieci oraz scharakteryzowano ich najistotniejsze zapisy.

Cel badawczy: Celem niniejszej pracy było zbadanie, czy sklepy internetowe funkcjonujące w Polsce respektują przepisy prawa i w jaki sposób przepisy te wpływają na obsługę klienta.

Metoda badawcza: Na potrzeby niniejszego opracowania Autorka przeprowadziła badania własne zarówno pośród klientów e-sklepów oraz kierowane do obsługi i pracowników sklepów elektronicznych. Badanie przeprowadzone zostało z wykorzystaniem kwestionariusza ankiety elektronicznej i odbyło się w 2019 r. Wyniki badań własnych zostały poszerzone o wyniki badań wtórnych, dzięki czemu możliwe było porównanie oczekiwań klientów co do poziomu obsługi z działaniami prowadzonymi przez sklepy.

Wyniki: Przeprowadzona analiza dotycząca respektowania przepisów prawnych przez e-sklepy oraz ich wdrażania w codziennej obsłudze klienta wykazała, że zarówno pracownicy sklepów internetowych, jak i sami klienci nie są w pełni świadomi swoich praw i obowiązków. Zdarza się, że sklepy internetowe nie umieszczają na swoich stronach obligatoryjnych informacji dla klientów, ci zaś nie zawsze wiedzą o możliwości np. zwrotu towaru bez podania przyczyny. Tymczasem w punktu widzenia klienta informacje o warunkach reklamacji i zwrotów, czy też dane adresowe e-sklepu stanowią fundament budowania wiarygodności podmiotu rynkowego.
\end{abstract}

Słowa kluczowe: e-handel, prawa klienta, aspekty prawne e-commerce.

Klasyfikacja JEL: L81, K24

* Dr, Uniwersytet Łódzki, Wydział Ekonomiczno-Socjologiczny, Katedra Logistyki i Innowacji; e-mail: dagmara.skurpel@uni.lodz.pl 


\section{Wstęp}

Polska należy do krajów o wysokiej dynamice rozwoju handlu on-line. Dzieje się tak za sprawą szybko rosnącej dostępności do Internetu, zwiększającej się z roku na rok liczby e-sklepów, poprawy infrastruktury w kanale e-handlu, a w efekcie poszerzania się kręgu osób dokonujących zakupów w sieci. Wzrost znaczenia handlu internetowego, a szerzej ujmując e-commerce, spowodował wzrost zainteresowania tą problematyką ze strony świata nauki, czego wyrazem są liczne publikacje ${ }^{1}$.

Budując swoją pozycję na rynku, marka powinna bazować na wartościach akceptowanych przez każdą z generacji konsumentów. Trzeba przy tym pamiętać, że należy elastycznie traktować zdiagnozowane wartości, obserwować pojawiające się zmiany, a także brać pod uwagę potrzeby indywidualnych konsumentów, które mogą się wyłamywać z ustalonych stereotypów ${ }^{2}$. Zmiany zachodzące na wirtualnych rynkach sprawiają, że jakość obsługi klientów nie jest stałym atutem przedsiębiorstwa, ale zasobem, który służy do budowania przewagi konkurencyjnej. Klient zwraca się do organizacji w nadziei, że spełni jego oczekiwania związane z wyrobem czy usługą, płaci także za nadzieję spełnienia tych oczekiwań3

$\mathrm{Z}$ drugiej strony regulacje prawne narzucają pewne działania na podmioty rynkowe, dając, głównie klientom, szeroki wachlarz praw. Sfera handlu elektronicznego regulowana jest $\mathrm{w}$ Polsce $\mathrm{z}$ jednej strony poprzez liczne akty prawne wspólne dla wszystkich przedsiębiorstw, z drugiej zaś, poprzez określone akty szczegółowe.

Warunki handlu internetowego wymagają odrębnych regulacji, ponieważ spotykają się z barierami - w świecie offline nie ma możliwości obejrzenia produktu przed zakupem czy też brak jest bezpośredniego kontaktu sprzedającego z kupującym - umowa zawierana jest na odległość. Działając w Internecie, sklepy internetowe przetwarzają też znacznie więcej danych osobowych niż ma to miejsce w sklepie stacjonarnym. Bariery te wymuszają na e-handlu znajomości podstawowych aktów prawnych, które przedstawione zostały i pokrótce scharakteryzowane w dalszej części niniejszego referatu.

\footnotetext{
B. Gregor, M. Kalińska-Kula, Rozwój handlu internetowego i jego uwarunkowania - perspektywa oferenta i nabywcy, Handel Wewnętrzny 2018/4 (375), s. 110.

2 H. Mruk, Marka w procesie kreowania wartości na rynku 4.0, w: B. Gregor, D. Kaczorowska-Spychalska, Marketing $w$ erze technologii cyfrowych, Wydawnictwo Naukowe PWN, Warszawa 2018, s. 113-114.

3 E. Skrzypek, Jakość i efektywność, Wydawnictwo Uniwersytetu Marii Curie-Skłodowskiej, Lublin 2000, s. 84.
} 
W niniejszym artykule podjęto próbę oceny wpływu regulacji prawnych na obsługę klientów w handlu elektronicznym, zarówno z perspektywy e-klientów, jak i samych e-sklepów. Uwaga autorki skupiła się głównie na ocenie aspektów związanych z logistyką zwrotną e-handlu ze względu na to, że to tego obszaru najczęściej dotyczą przepisy prawa. Referat ma charakter teoretyczno-empiryczny, a jego fundament stanowi przegląd literatury przedmiotu. Część empiryczna natomiast jest oparta na wynikach badań własnych przeprowadzonych przez autorkę zarówno po stronie popytowej, jak i podażowej rynku e-commerce. Badania klientów sklepów internetowych przeprowadzane były w okresie sierpień 2019 r. - wrzesień 2019 r. Link do kwestionariusza ankiety internetowej został upubliczniony na portalu społecznościowym Facebook. Dobór respondentów do próby badawczej miał charakter przypadkowy, tzw. wygodny. W badaniu wzięło udział 2246 osób, z czego 1984 respondentów zadeklarowało, że dokonało zakupów w Internecie i to te osoby poproszone były o udzielenie odpowiedzi na pytania zamieszczone w kwestionariuszu. Badanie e-sklepów również odbyło się za pomocą kwestionariusza ankiety w formie elektronicznej, a zaproszenia do badania zostały wysłane drogą mailową. Łącznie wysłanych zostało 9987 wiadomości z zaproszeniem do udziału w badaniu. Otrzymano 135 poprawnie wypełnionych kwestionariuszy, co stanowi zwrot na poziomie $1,35 \%$. Wyników badania e-sklepów nie można uznać za reprezentatywne dla całej populacji, jednak mają istotne znaczenie ilustrujące badany problem. Spośród 135 respondentów 122 firmy zadeklarowały, iż prowadzą sprzedaż za pośrednictwem Internetu, dlatego dalsze wyniki badań odnosiły się do tej grupy przedsiębiorstw.

\section{Czynniki kreujące funkcjonowanie e-commerce w Polsce}

Początki handlu internetowego w Polsce sięgają połowy lat 90. ubiegłego wieku. Jeszcze dekadę temu stanowił on ułamek sprzedaży detalicznej, a dziś sprzedaż w sieci zmienia obraz handlu, przyczyniając się do zmiany funkcji tradycyjnych sklepów, które często stają się bardziej salonami wystawowymi niż miejscami dokonywania zakupów ${ }^{4}$.

Intensywny rozwój e-biznesu jest warunkowany istnieniem korzyści, które są generowane w następstwie wykorzystywania przez handel elektroniczny

4 B. Gregor, M. Kalińska-Kula, Rozwój handlu internetowego i jego uwarunkowania... 
różnych modeli i narzędzi wykorzystujących najnowsze technologie. Poza nimi największy wpływ na intensywny rozwój e-biznesu mają

- $\quad$ stały wzrost prędkości Internetu, dzięki któremu przedsiębiorstwa w znacznie sprawniejszy sposób mogą prezentować swoją ofertę klientom, a także realizować procesy sprzedażowe czy marketingowe, a klienci szybciej wyszukiwać i porównywać oferty,

- wzrost mobilności społeczeństwa i dostęp do urządzeń takich jak smartfony i tablety,

- zwiększenie zainteresowania outsourcingiem (przekazywanie realizacji niektórych czynności i procesów innym, wyspecjalizowanym przedsiębiorstwom) oraz partnerstwem z innymi firmami,

- orientacja na integrowanie wszystkich obszarów funkcjonowania firm, w tym na przykład systemu wejść i wyjść oraz księgowości,

- wzrost oczekiwań klientów, który dotyczy na przykład płynności w świadczeniu usług, przejrzystości realizowanych czynności czy pełnego zautomatyzowania procesu obsługi klientów, co z kolei prowadzi do tego, że poszczególne przedsiębiorstwa zostają wręcz zmuszone do tworzenia odpowiedniej infrastruktury i wdrażania procedur realizowanych za pośrednictwem Internetu.

Odsetek konsumentów przekonanych do zakupów w Internecie rok rocznie zwiększa się $e^{6}$. Wynika to $\mathrm{z}$ istotnych przewag tej formy handlu w porównaniu $\mathrm{z}$ handlem tradycyjnym, m.in. możliwości dokonywania zakupów bez wychodzenia z domu, dostępności całą dobę, niższych cen, prawnej możliwości zwrotu towaru, który nie spełni oczekiwań. Nie bez znaczenia dla potencjalnego e-nabywcy są również usprawnienia logistyczne w obsłudze klienta, znajdujące swój wyraz w poszerzającej się ofercie form dostaw zamówionych produktów i sposobów płatności. Zakupy w Internecie stają się więc dla konsumenta coraz szybsze i, co ważne, coraz bezpieczniejsze. Podnosi się jakość obsługi, co jest efektem nie tylko działań marketingowych po stronie przedsiębiorców, ale również regulacji prawnych. Sprzedawcy on-line są coraz bardziej świadomi potrzeby kreowania pozytywnych doświadczeń nabywców w ich wzajemnych kontaktach handlowych. To bowiem te doświadczenia są najważniejszą - w opinii e-konsumentów - determinantą wyboru określonego sklepu.

5 G.A. Garrett, G.A. Parrott, E-Business - Understanding Key Trends and Applaying Best Practices, Contract Management 2005/7, s. 35-41.

6 Poradnik E-commerce, Materiał przygotowany przez Grupę Roboczą E-commerce działającą w ramach IAB Polska, https://iab.org.pl/wp-content/uploads/2019/07/Poradnik-ECommerce-2019.pdf; stan na 4.01.2020 r. 
Przyzwyczajenie sprawia, że konsument, który ma pozytywny stosunek do marki produktu lub sklepu i zmienia ją, jeśli tylko zostaje zastosowana w stosunku do niego odpowiednia zachęta lub dotychczasowy sklep popełnił w oczach klienta jakiś błąd, natomiast lojalność to wierność marce, która opiera się na silnym, emocjonalnym fundamencie i za którą idą powtarzalne i świadome wybory - nawet w przypadku wystąpienia problemów?

Nie ulega wątpliwości, że to właśnie nabywcy są grupą, na której przedsiębiorstwa powinny koncentrować gros swoich działań, dążąc do zbudowania długotrwałych, zyskownych i obopólnie korzystnych relacji, których podstawą jest dostarczenie klientom oczekiwanego poziomu obsługi oraz poczucia bezpieczeństwa ${ }^{8}$.

\section{Regulacje prawne handlu elektronicznego}

Niemal w każdym państwie w inny sposób uregulowano kwestie prawne odnoszące się do funkcjonowania e-commerce. Niemniej jednak, istnieją wspólne dla prawa międzynarodowego czy unijnego przepisy dotyczące tego biznesu.

Jeśli chodzi o unormowania międzynarodowe, to pierwsze próby kompleksowego regulowania kwestii odnoszących się do e-biznesu podjęto w latach 90. $\mathrm{XX}$ w., co miało integralny związek z tym, że to właśnie w tym okresie biznes elektroniczny zaczął rozwijać się na szczególnie dużą skalę. Jednym z pierwszych dokumentów, w którym odniesiono się do zagadnień związanych z e-biznesem, był opublikowany w grudniu 1996 r. dokument UNCITRAL (United Nations Commission on International Trade Law), a więc Komisji ds. Prawa Handlu Międzynarodowego ONZ, zatytułowany „Model prawny UNCITRAL dla handlu elektronicznego z przewodnikiem realizacyjnym"”.

Bardzo ważne znaczenie dla polskiego e-biznesu mają uregulowania przyjęte na szczeblu Unii Europejskiej. Pierwsze próby sformułowania takich uregulowań miały miejsce już w latach siedemdziesiątych 70 . XX w., co miało związek z budową społeczeństwa informacyjnego i rozpoczęciem pięcioletniego eksperymentalnego programu pod nazwą ,Forecasting and Assessment in the Field of Science

7 K. Pawlikowska, M. Poleszak, Czujesz, czyli o komunikacji marketingowej i sprzedaży skierowanej do kobiet, CeDeWu.pl, Warszawa 2011, s. 144.

8 J. Bramham, Benchmarking $w$ zarządzaniu zasobami ludzkimi, Oficyna Ekonomiczna, Kraków 2004, s. 107.

9 A. Wawszczyk, E-gospodarka. Poradnik przedsiębiorcy, Polska Agencja Rozwoju Przedsiębiorczości, Warszawa 2003, s. 17-19. 
and Technology" (FAST). Intensywny rozwój unormowań unijnych dotyczących e-biznesu miał miejsce w latach 90. XX w. oraz na początku XXI w. Jego zwieńczeniem było uchwalenie Dyrektywy Parlamentu Europejskiego i Rady 2000/31/ WE z dnia 8 czerwca $2000 \mathrm{r}$. w sprawie niektórych aspektów prawnych usług społeczeństwa informacyjnego, w szczególności handlu elektronicznego w ramach rynku wewnętrznego, która jest również nazywana „dyrektywą o handlu elektronicznym"10. Dyrektywa ma na celu przyczynienie się do sprawnego funkcjonowania rynku wewnętrznego, zapewniając swobodny przepływ usług w społeczeństwie informacyjnym między państwami członkowskimi - art. 1, ust. 1. Ponadto reguluje prawa i obowiązki usługodawców i usługobiorców usług społeczeństwa informacyjnego. Świadczenie usług drogą internetową podlegać powinno zasadzie transparentności usługodawcy i poszanowania prywatności usługobiorcy. Dyrektywa zawiera specjalne zasady ochrony danych osobowych usługobiorcy. Ochrona ta, poza zasadami ogólnymi, polegać powinna na przetwarzaniu danych wyłącznie (z pewnymi wyjątkami) za zgodą usługobiorcy. Dane powinny być ograniczone do niezbędnego minimum, koniecznego do wywiązania się z umowy o świadczenie usługi. Użytkownik powinien mieć prawo korzystania z usług anonimowo lub przy użyciu pseudonimu ${ }^{11}$.

Jeśli chodzi o prawo krajowe, to do kwestii związanych z e-biznesem podchodzi ono w bardzo szeroki sposób, przy czym jednak istnieje w tym zakresie ustawowy chaos, przedsiębiorcy są pewni, że znają prawo i przed skutkami jego niestosowania są w pełni zabezpieczeni. Tymczasem tak wcale nie jest. Przykładem może być sytuacja opisana numerze „Mensis. pl”. Na pytanie o ustawę, która reguluje działalność sklepów internetowych, blisko 60\% właścicieli sklepów wybrało ustawę, która była wyłącznie imaginacją autora. Daje to pogląd na ogromny problem związany z brakiem odpowiedniej wiedzy z zakresu uregulowań prawnych prowadzenia e-handlu ${ }^{12}$.

Niewątpliwie w najbardziej wyczerpujący i kompleksowy sposób kwestie dotyczące e-biznesu reguluje Ustawa z dnia 18 lipca 2002 r. o świadczeniu usług drogą elektroniczną ${ }^{13}$. Określono w niej między innymi obowiązki, jakie musi wypełnić osoba prowadząca e-biznes. Zaliczono do nich przede wszystkim konieczność przekazywania usługobiorcom informacji na temat imienia, nazwiska i adresu firmy oraz jej adresów elektronicznych, jak również omówiono zasady ochrony danych osobowych tych osób fizycznych, które korzystają z usług świadczonych za pomo-

\footnotetext{
K. Bartczak, Bariery rozwojowe handlu elektronicznego, Exante, Wrocław 2016, s. 21.

R. Szulc, A. Kobylański, E-biznes, Uniwersytet Warmińsko-Mazurski, Olsztyn 2014, s. 87.

Ibidem, s. 88.

13 Ustawa o świadczeniu usług drogą elektroniczną, Dz.U. z 2002 r., nr 144, poz. 1204.
} 
cą drogi elektronicznej (wspomniane dane mogą być wykorzystywane tylko w celu realizacji umów lub dokonywania innych czynności prawnych).

Urząd Ochrony Konkurencji i Konsumentów może uznać, że firma, nie podając wszystkich informacji przewidzianych prawem, działa na szkodę konsumentów i w związku z tym wytoczyć jej postępowanie administracyjne. Ponadto firmy konkurencyjne mogą to uznać za element nieuczciwej konkurencji.

Drugim istotnym aktem prawnym w polskim prawodawstwie jest dla e-handlu ustawa z dnia 2 marca 2000 r. o ochronie niektórych praw konsumentów oraz o odpowiedzialności za szkodę wyrządzoną przez produkt niebezpieczny ${ }^{14}$, która stanowi próbę implementacji zapisów unijnej dyrektywy nr 97/7 z dnia 20 maja 1997 r. w sprawie ochrony konsumentów w przypadku umów zawieranych na odległość. Podkreślić należy, że zawiera ona niezmiernie istotną definicję umowy kupna-sprzedaży zawieranej na odległość, którą w myśl art. 6 ww. ustawy należy rozumieć jako: „Umowy zawierane z konsumentem bez jednoczesnej obecności obu stron, przy wykorzystaniu środków porozumiewania się na odległość, w szczególności drukowanego lub elektronicznego formularza zamówienia niezaadresowanego lub zaadresowanego, listu seryjnego w postaci drukowanej lub elektronicznej, reklamy prasowej z wydrukowanym formularzem zamówienia, reklamy w postaci elektronicznej, katalogu, telefonu, telefaksu, radia, telewizji, automatycznego urządzenia wywołującego, wizjofonu, wideo tekstu, poczty elektronicznej lub innych środków komunikacji elektronicznej w rozumieniu ustawy z dnia 18 lipca 2002 r. o świadczeniu usług drogą elektroniczną są umowami na odległość, jeżeli kontrahentem konsumenta jest przedsiębiorca, który w taki sposób zorganizował swoją działalność". Dodatkowo podkreśla się fakt, że posłużenie się telefonem, telefaksem, pocztą elektroniczną, automatycznym urządzeniem wywołującym lub innym środkiem komunikacji elektronicznej w celu złożenia propozycji zawarcia umowy może nastąpić wyłącznie za uprzednią zgodą konsumenta.

Niezmiernie ważne jest również to, że w myśl niniejszej ustawy przedsiębiorca zobowiązany jest do poinformowania konsumenta (najpóźniej w chwili złożenia mu propozycji zawarcia umowy) $\mathrm{o}^{15}$ :

- imieniu i nazwisku (nazwie), adresie zamieszkania (siedziby) przedsiębiorcy oraz organie, który zarejestrował działalność gospodarczą przedsiębiorcy, a także numerze, pod którym przedsiębiorca został zarejestrowany,

14 Ustawa z dnia 2 marca 2000 r. o ochronie niektórych praw konsumentów oraz o odpowiedzialności za szkodę wyrządzoną przez produkt niebezpieczny, Dz.U. z 2000 r., nr 22, poz. 271.

15 M. Lewicki, Instrumenty tworzenia wartości dla klienta $w$ handlu elektronicznym, http:// www.wbc.poznan.pl/Content/251091/M.Lewicki-Instrumenty_tworzenia_wartosci_dla_ klienta_w_handlu\%20elektronicznym.pdf; stan na 20.04.2019 r. 
- istotnych właściwościach świadczenia i jego przedmiotu,

- cenie lub wynagrodzeniu obejmujących wszystkie ich składniki, a w szczególności cła i podatki,

- zasadach zapłaty ceny lub wynagrodzenia,

- kosztach oraz terminie i sposobie dostawy,

- prawie odstąpienia od umowy w terminie dziesięciu dni, ze wskazaniem wyjątków, o których mowa w art. 10 ust. 3,

- $\quad$ kosztach wynikających z korzystania ze środków porozumiewania się na odległość, jeżeli są one skalkulowane inaczej niż wedle normalnej taryfy,

- terminie, w jakim oferta lub informacja o cenie albo wynagrodzeniu mają charakter wiążący,

- minimalnym okresie, na jaki ma być zawarta umowa o świadczenia ciągłe lub okresowe,

- miejscu i sposobie składania reklamacji,

- $\quad$ prawie wypowiedzenia umowy, o którym mowa w art. 8 ust. 3.

Ustawa podkreśla ponadto, że przedsiębiorca powinien wykonać umowę zawartą na odległość najpóźniej w terminie 30 dni po złożeniu przez konsumenta oświadczenia woli o zawarciu umowy (chyba że strony umówiły się inaczej). W przypadku zaś niemożności wykonania świadczenia powinien on niezwłocznie poinformować o tym fakcie konsumenta.

Aktem prawnym, w znaczącym stopniu wpływającym na handel elektroniczny, była Ustawa z dnia 30 maja 2014 r. o Prawach konsumenta ${ }^{16}$, która weszła w życie 25 grudnia 2014 r. Główne obowiązki nałożone przez Ustawę na właścicieli sklepów to ${ }^{17}$ :

- Obowiązek informacyjny - wszystkie informacje o prawach i obowiązkach konsumenta powinny być mu przekazane w sposób czytelny, zrozumiały i jasny najpóźniej w chwili złożenia propozycji zawarcia umowy na odległość, czyli powinny być zamieszczone na stronie sklepu.

- Obowiązek potwierdzenia zawarcia umowy - konsument powinien otrzymać potwierdzenie zawarcia umowy na trwałym nośniku (w tym pocztą elektroniczną) w odpowiednim czasie, ale najpóźniej w chwili dostarczenia mu przedmiotu umowy.

- Konieczność wprowadzenia zmian w procesie zakupowym - konsument musi wyrazić wyraźną zgodę na każdą dodatkową płatność, najpóźniej w chwili wyrażenia woli zawiązania umową. Dodatkowo sprzedający musi

\footnotetext{
Ustawa z dnia 30 maja 2014 r. o Prawach konsumenta, Dz.U. z 2014 r., poz. 827.
}

17 Poradnik E-commerce... 
zapewnić techniczną możliwość, aby konsument w momencie składania zamówienia wyraźnie potwierdził, że jest świadomy, iż zamówienie niesie ze sobą obowiązek zapłaty - może się to odbyć poprzez dodanie do przycisku zamówienia sformułowania „Zamawiam z obowiązkiem zapłaty”.

- Wydłużenie terminu odstąpienia od umowy - konsument ma prawo odstąpić od umowy zawartej na odległość w terminie 14 dni na odpowiednim formularzu (wzór oświadczenia podany w Ustawie). Jeżeli konsument nie zostanie o tym poinformowany, okres odstąpienia wydłuża się do 12 miesięcy. Decydując się na taki krok, należy poinformować o tym fakcie sprzedawcę w ciągu 14 dni, licząc od daty zawarcia umowy, najlepiej w formie pisemnego oświadczenia przesłanego poczta tradycyjną, a następnie w ciągu następnych dwóch tygodni odesłać kupiony przedmiot ${ }^{18}$.

$\mathrm{Z}$ racji tego, że korzystanie z produktów i usług oferowanych przez e-biznes wiąże się w nierozerwalny sposób z powstaniem zagrożenia dla ochrony danych osobowych, wśród podstawowych aktów prawnych odnoszących się do tego rodzaju biznesu należy również wspomnieć o tych, które kształtują regulacje na temat ochrony danych osobowych. Mowa tutaj przede wszystkim o Ustawie z dnia 29 sierpnia 1997 r. o ochronie danych osobowych ${ }^{19}$. Ponadto należy wspomnieć o Rozporządzeniu Ogólnym o Ochronie Danych Osobowych ${ }^{20}$ (polski skrót RODO), które zostało przyjęte w dniu 25 maja 2016 r., na podstawie rozporządzenia Parlamentu Europejskiego i Rady (UE) 2016/679 z dnia 27 kwietnia 2016 r.

Na mocy rozporządzenia z dniem 25 maja 2018 r. zaczęły obowiązywać nowe regulacje $\mathrm{w}$ zakresie ochrony i przetwarzania danych osobowych osób fizycznych w państwach członkowskich UE.

Najważniejsze obowiązki, jakie wprowadziło RODO, z punktu widzenia sklepu internetowego to ${ }^{21}$ :

- Zbieranie zgód - Administrator ma obowiązek zbierania zgód, które powinny być wyrażone w sposób świadomy, a ich treść powinna być jasna dla użytkownika. Użytkownik powinien być zawsze poinformowany, jakie dane osobowe, przez kogo i w jakim celu będą przetwarzane.

- Konieczność uzyskania osobnej zgody na profilowanie - czyli na zbieranie danych na temat użytkownika (np. jego zachowania na stronie sklepu,

$18 \mathrm{https} / /$ ceo.com.pl/regulacje-prawne-handlu-sklepow-internetowych-prawa-e-konsumenta-33573; stan na 31.12.2019 r.

19 Ustawa z dnia 29 sierpnia 1997 r. o ochronie danych osobowych, Dz.U. z 1997 r., nr 133, poz. 883.

20 Ogólne rozporządzenie o ochronie danych, Dziennik Urzędowy Unii Europejskiej L 119, 4 maja 2016.

${ }^{21}$ Poradnik E-commerce... 
zakupów i lokalizacji) i na tej podstawie przypisywanie go do danego segmentu klientów (np. w celu remarketingu).

- Obowiązek prowadzenia rejestru-Administrator ma obowiązek prowadzić rejestr czynności przetwarzania danych osobowych (na temat innych administratorów, celów przetwarzania, stosowanych zabezpieczeń, systemów i innych).

- Obowiązek zgłaszania naruszenia danych osobowych - Administrator Danych Osobowych ma 72 godziny na zgłoszenie incydentu do organu nadzoru.

- $\quad$ Przesyłanie danych poza UE - w przypadku przekazywania danych poza UE należy zagwarantować szczególny poziom bezpieczeństwa dla przekazania i dla dalszego ich przetwarzania (zgodny z RODO). Jest to jeden $\mathrm{z}$ bardziej kontrowersyjnych punktów, ze względu na dużych reklamodawców z serwerami poza granicami UE - Facebooki Google.

- Kary - wprowadzenie możliwości nałożenia kary za niestosowanie się do rozporządzenia (do 4\% rocznego obrotu przedsiębiorstwa lub $20 \mathrm{mln}$ euro).

Sklepy internetowe powinny zastosować rozporządzenia RODO zarówno w kwestiach proceduralnych (np. zbierania zgód na przetwarzanie danych osobowych), jak i formalnych (nowe wzory dokumentów, treści zgód).

Na stronie każdego sklepu internetowego muszą się znaleźć widoczne dla kupujących ceny oferowanych towarów oraz ich ceny jednostkowe (cena za jednostkę miary, np. litr, kilogram). Taki sam sposób podawania cen powinien być stosowany również $\mathrm{w}$ reklamie sklepu zamieszczonej na innych stronach WWW. Sprzedający w Polsce muszą też udzielić kupującemu jasnych, zrozumiałych i niewprowadzających w błąd informacji w języku polskim (mają wystarczyć do prawidłowego i pełnego korzystania ze sprzedanego towaru).

Gdyby pojawiły się problemy z realizacją zamówienia i wyegzekwowaniem praw przez klienta, można skorzystać z pomocy instytucji, które pomagają konsumentom w takich sytuacjach. W pierwszej kolejności warto zwrócić się do Rzecznika Konsumentów i Urzędu Ochrony Konkurencji i Konsumentów. Z kolei w przypadku, gdy sprzedawca okazałby się nieuczciwy i mimo zapłaty zwleka $\mathrm{z}$ wysyłką towaru i unika z klientem kontaktu, należy zgłosić taki fakt na Policję.

\section{Obsługa klienta w handlu elektronicznym w kontekście przeprowadzonych badań własnych}

Zachowanie i oczekiwania uczestnika jakiejkolwiek interakcji społecznej są zdeterminowane przez normy społeczne i prawne, role, porozumienia i obyczaje oparte na doświadczeniach z przeszłości, co znajduje odzwierciedlenie 
w prezentowanych przez poszczególne pokolenia wspólnych ideach, wypracowanych kodach komunikacyjnych czy systemach wartości przejawiających się określonym stosunkiem do otaczającego ich świata ${ }^{22}$.

W przypadku e-sklepów zaobserwować można typowe dla środowiska Internetu zjawisko zwane efektem sieciowym ${ }^{23}$. Większa liczba osób korzystających $z$ danego serwisu e-commerce, pozytywny wizerunek i dobra reputacja serwisu, a także zamieszczane w sieci przez konsumentów opinie, recenzje i komentarze zwiększają zaufanie, wpływając na wzrost poczucia bezpieczeństwa konsumentów i minimalizowanie niepewności transakcji ${ }^{24}$.

Za najważniejsze czynniki, determinujące obsługę e-konsumentów uznaje się zaufanie i satysfakcję klientów. Zaufanie jest to wiedza lub wiara, że jego działania, przyszły stan lub własności okażą się zgodne z życzeniem klienta. Ufając komuś czy też czemuś klient wchodzi w pewien układ z tą drugą stroną. Zaufanie można zdefiniować jako poddające się subiektywnej ocenie prawdopodobieństwa przekonanie, na podstawie którego jednostka (A) w konkretnej sytuacji zgadza się na zależność od jednostki (B) - osoby, instytucji, przedmiotu itp., mając poczucie względnego, określonego tym prawdopodobieństwem bezpieczeństwa, mimo że negatywne konsekwencje są możliwe ${ }^{25}$. Zaufanie wpływa przede wszystkim na długość i prawdopodobieństwo kontynuowania relacji z firmą, zwiększone zakupy oraz nabywanie w danym sklepie produktów innej kategorii.

Zaufanie $\mathrm{w}$ biznesie jest pochodną wiarygodności stron zawierających transakcje. Wiarygodność nie jest cechą jednoznaczną i oczywistą. Każdy jej adresat inaczej może ją postrzegać i oceniać. Coś co w jednych budzi zaufanie, innych może razić i zniechęcać. Kluczowym elementem jest tutaj źródło informacji, na bazie którego wydajemy opinię na dany temat. W obecnych czasach

22 B. Gregor, D. Kaczorowska-Spychalska, Homo Cyber Oeconomicus - nowy wymiar zachowań konsumenckich, w: B. Gregor, D. Kaczorowska-Spychalska, Marketing w erze technologii cyfrowych, Wydawnictwo Naukowe PWN, Warszawa 2018, s. 63-64.

23 Efekt zewnętrzny sieci ma miejsce wówczas, gdy wartość produktu lub usługi dla użytkownika jest zdeterminowana przez to, ilu konsumentów korzysta $\mathrm{z}$ tego produktu/usługi. Jednym ze skutków występowania tego efektu jest to, że każdy dodatkowy użytkownik sieci przynosi korzyści dotychczasowym jej uczestnikom. Innymi słowy, efekt sieci sprawia, że wartość produktu lub usługi jest kreowana przez użytkowników, a nie przez producenta. Zob. więcej:

D. Begg, S. Fisher, R. Dornbush, Mikroekonomia, PWE, Warszawa 2007, s. 437.

24 H. Tsai, H. Huang, Online Consumer Loyalty: Why E-Tailers Shouldseek a High-Profile Leadership Position, Computers in Human Behavior 2009/25, s. 1236-1237.

25 T. Zieliński, Zaufanie jako regulator decyzji ekonomicznych (analiza literatury), Management and Business Administration. Central Europe 2012/4, s. 73-91. 
dostęp do informacji jest niemal bezgraniczny, ale część z nich może być napisana przez niegodne zaufania źródła ${ }^{26}$.

WYKRES 1: Aspekty wptywajace na przekonanie klienta, że ten sklep jest wiarygodny (możliwy wielokrotny wybór odpowiedzi)

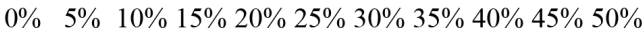

opinie o tym sklepie internetowym możliwość płatności przy odbiorze jasna i czytelna informacja nt. zwrotu i reklamacji dostępne różne formy płatności adres biura w Polsce ładna i czytelna prezentacja produktów dane teleadresowe fizyczne punkty odbioru znaki jakości i certyfikaty zaufania informacje o gwarancji regulamin możliwość zakupu na raty graficzny wygląd sklepu zdjęcie siedziby sklepu stacjonarnego logotypy banków w płatnościach ciekawy fanpage lub blog adres biura za granica nie wiem\ trudno powiedzieć

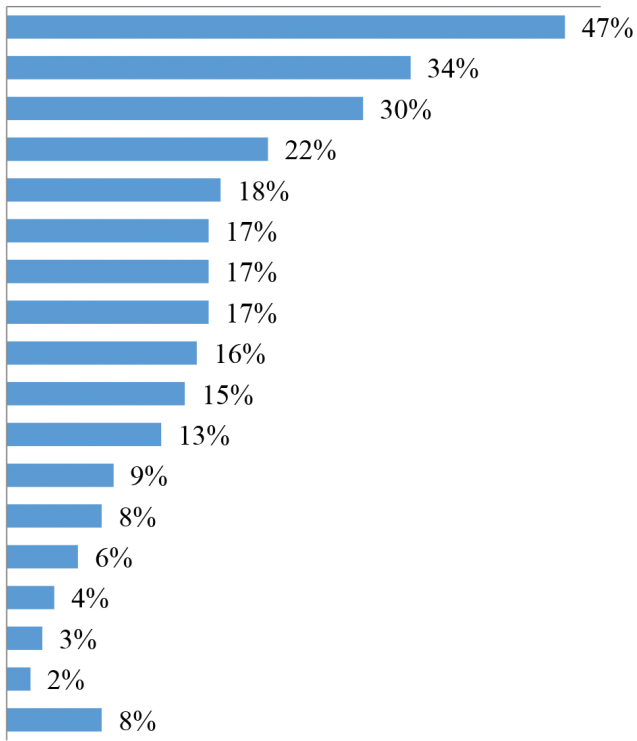

Źr ó dło: opracowanie własne na podstawie: Raport E-Commerce w Polsce. Gemius dla e-Commerce Polska.

Każdy klient chce mieć pewność, że transakcja zawarta przez Internet zakończy się pomyślnie i otrzyma on zamówiony towar, a przedsiębiorstwu przyniesie zyski. Przed złożeniem zamówienia potencjalny kontrahent sprawdza wiarygodność e-sklepu w celu uniknięcia ewentualnego ryzyka ${ }^{27}$.

Według badań Gemius przeprowadzonych dla Izby Gospodarki Elektronicznej ${ }^{28}$ klienci oceniają wiarygodność sklepu internetowego przede wszyst-

26 B. Krawczyk-Bryłka, Hybrydowy model zaufania w Internecie, Zeszyty Naukowe Uniwersytetu Szczecińskiego 2009/541, Gdańsk, s. 51.

27 Zob. więcej: A. Lew, Oszustwa księgowe w obszarze przychodów i kosztów wpływające na wiarygodny obraz jednostki gospodarczej wykrywane przez biegłego rewidenta, Prace Naukowe Uniwersytetu Ekonomicznego we Wrocławiu 2017/471, Wrocław, s. 301.

28 Raport E-Commerce w Polsce. Gemius dla e-Commerce Polska, kwiecień 2019. 
kim na podstawie opinii innych konsumentów, którzy skorzystali z oferty sprzedawcy (wykres 1). Jako kolejne czynniki wskazano możliwość płatności przy odbiorze, a na trzecim miejscu znalazły się informacje dotyczące warunków zwrotu i reklamacji. Warto zauważyć, że na kolejnych pozycjach znalazły się takie aspekty, jak: dane adresowe, informacje o gwarancji oraz regulamin zakupów, czyli informacje, które zgodnie z prawem powinny znaleźć się na stronie każdego e-sklepu bez wyjątku.

Prawo nie jest jednak respektowane przez każdy sklep internetowy. Jak można zauważyć na wykresie 2, prawie każdy e-sklep udostępnia na swojej stronie dane kontaktowe, najczęściej adres e-mail lub formularz kontaktowy, nieco rzadziej numer telefonu. Aż 95\% respondentów publikuje warunki dostawy, 88\% regulamin, a warunki zwrotów i reklamacji zamieszcza 8 na 10 e-sklepów. Jedynie 3/4 z podmiotów rynku podaje adres swojej siedziby. Brak podstawowych informacji, które powinny znaleźć się na stronie internetowej sklepu elektronicznego, powoduje, że w ocenie klientów taki sprzedający nie jest wiarygodny, a co za tym idzie, może nie prowadzić legalnej sprzedaży. Klienci obawiają się przede wszystkim kłopotów ze zwrotem zakupionego towaru, w szczególności ze zwrotem pieniędzy. Korzystanie z Internetu w celu przeprowadzenia transakcji zakupu-sprzedaży daje także podstawy do obaw o bezpieczeństwo, poufność przekazu, zachowania nieuczciwe lub też naruszanie praktyk i obyczajów działalności gospodarczej.

WYKRES 2: Informacje publikowane na stronach internetowych e-sklepów (możliwy wielokrotny wybór odpowiedzi)

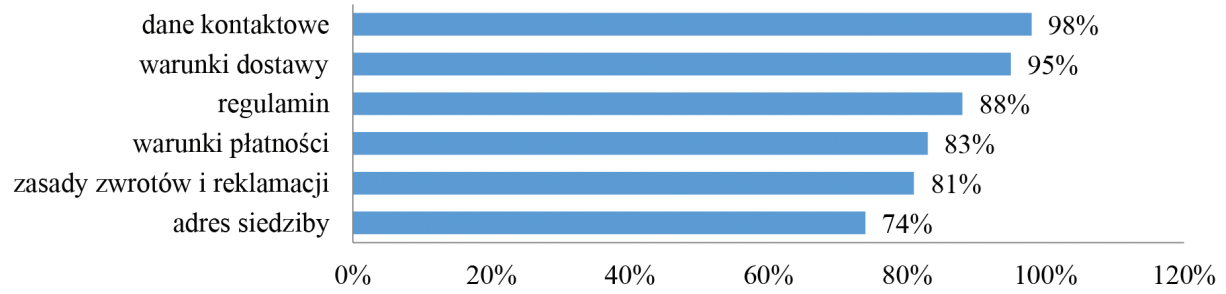

Źr ó dło: opracowanie własne.

Zwroty towarów są nieodzowną częścią prowadzenia sprzedaży w sieci ze względu na specyfikę e-commerce wyrażającą się poprzez brak osobistego kontaktu z klientem oraz brak możliwości fizycznego obejrzenia towaru.

Co ważne - warunki zwrotów i reklamacji są jednym z podstawowych kryteriów kreowania wiarygodności e-sklepu, gdyż 92\% klientów, którzy wzięli 
udział w badaniach, wie, że zgodnie z polskim prawem można zwrócić zakupiony w Internecie towar w ciągu 14 dni bez podawania jakiejkolwiek przyczyny.

Znając swoje prawa, klienci mogą korzystać z takiej możliwości nie tylko wtedy, gdy produkt okaże się być nietrafionym zakupem, ale również w przypadku, gdyby produkt $w$ ciągu dwóch tygodni uległ awarii. Niestety, mimo że prawo narzuca konieczność informowania klientów o tym przywileju, $6 \%$ sklepów internetowych nie udostępnia takiej informacji (wykres 3).

WYKRES 3: Informowanie o możliwości zwrotu towaru w ciagu 14 dni

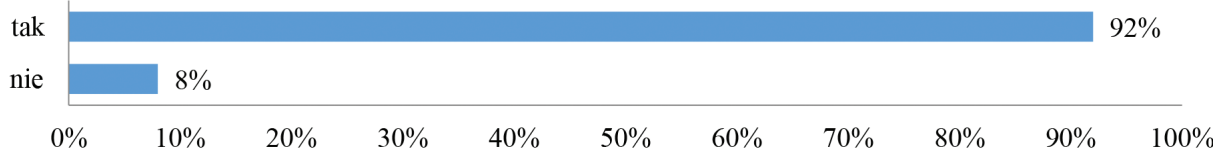

Źródło: opracowanie własne.

Zwrot w sklepie internetowym to bez wątpienia problematyczna kwestia dla wielu sprzedawców. Ustawa o prawach konsumenta w art. 38 wymienia sytuacje, w których zwrot w sklepie internetowym nie jest możliwy, ale zostawia też przedsiębiorcy pewną swobodę decydowania, czy przyjmie on zwrócony towar. Ma to zastosowanie zwłaszcza w sytuacji, gdy towar został uszkodzony lub zabrudzony w takim stopniu, że niemożliwe jest sprzedanie go po raz drugi. Jednak nawet w przypadku, gdy sprzedawca odmówi przyjęcia zwrotu, powinien odpowiednio uargumentować swoją decyzję i podać wyraźnie przyczyny - klient może zwrócić się do Rzecznika Praw Konsumenta, a do Rejestru Klauzul Niedozwolonych prowadzonego przez Urząd Ochrony Konkurencji i Konsumentów mogą trafić nie tylko sformułowania z uzasadnienia odmowy, ale także zapisy regulaminu e-sklepu.

Jak pokazują przeprowadzone badania, ponad połowa zapytanych klientów, a dokładnie 52\% dokonała przynajmniej raz zwrotu towaru do sklepu internetowego. Najczęstszą przyczyną odesłania zamówienia jest wspomniana już możliwość skorzystania z prawa zwrotu bez podania przyczyny (46\% ankietowanych) - wykres 4. Świadczy to o tym, że klienci e-sklepów nie tylko mają świadomość swoich praw, ponadto bezproblemowo przeprowadzony proces zwrotu czy reklamacji zachęci klienta do ponownego korzystania z usług sklepu.

Spośród klientów, którzy reklamowali towar, 9\% zgłosiło, iż w procesie reklamacyjnym napotkali problemy wiążące się z odmową e-sklepu do przyjęcia towaru, brakiem jakiejkolwiek odpowiedzi ze strony obsługi sklepu lub koniecznością wielokrotnego upominania się o zwrot pieniędzy. 
WYKRES 4: Powody zwrotów wskazane przez klientów (możliwy wielokrotny wybór odpowiedzi)

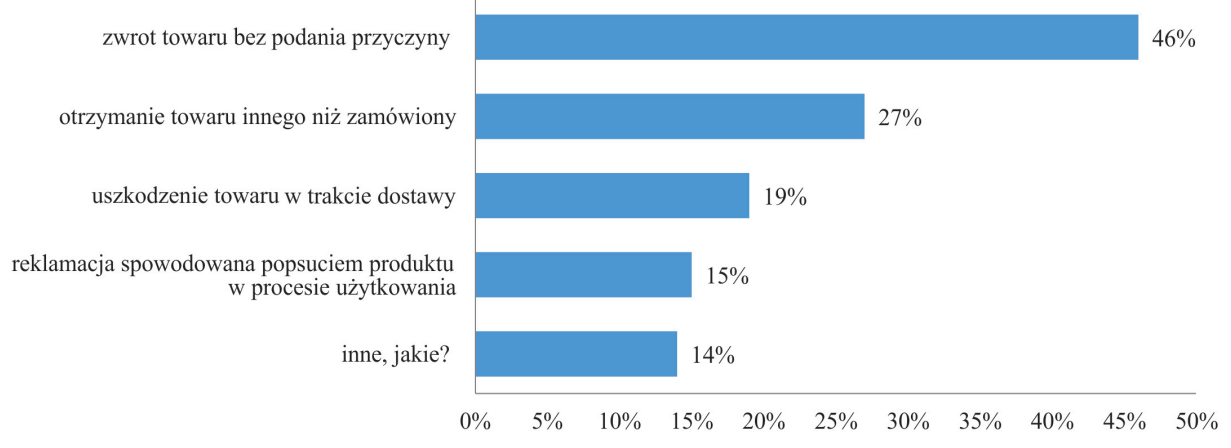

Źr ódło: opracowanie własne.

Proces reklamacji w sklepach elektronicznych jest oceniany pozytywnie, ale koszt odesłania towaru oraz czas naprawy to nadal aspekty budzące wątpliwości. Sklepy internetowe powinny mieć w tej kwestii na uwadze, że obsługa klienta ze strony sklepu i ponoszone przez klienta koszty stanowią atrybut wartości. Dlatego też istotne jest to, by nie obciążać kosztami zwrotów klientów, szczególnie w sytuacji, gdy zwrot jest wynikiem błędnego wysłania towaru.

Reklamacje to ponadto informacja dla dostawcy, że występują błędy w procesie dostarczania zamówienia. Dlatego też nie można ich traktować personalnie, ale trzeba wyciągać wnioski z nieprawidłowości związanych z dostawą lub produktem.

\section{Zakończenie}

Rozwój handlu prowadzonego w cyberprzestrzeni, zarysowany w pierwszej części niniejszych rozważań, sprawia, że aktualne stają się pewne zagadnienia dotyczące infrastruktury prawnej (zarówno w zakresie ustawodawstwa, jak i przepisów wykonawczych) leżącej u podstaw działalności internetowej.

Biorąc pod uwagę wyniki badań własnych związanych z handlem elektronicznym, można wskazać w zarysie kilka obszarów problemowych, z którymi musi się liczyć organizacja zamierzająca prowadzić handel elektroniczny poprzez Internet. Należą do nich: obowiązek informacyjny, zwiększona presja ze strony klientów co do szybkości bezpieczeństwa obsługi, prawa do ochrony danych oraz niepewność co do statusu umów zawieranych drogą elektroniczną. 
Warunki handlu internetowego wymagają odrębnych regulacji, ponieważ spotykają się z barierami - w świecie offline doskwiera klientom brak możliwości obejrzenia produktu przed zakupem czy też brak bezpośredniego kontaktu sprzedającego z kupującym. Działając w Internecie, przetwarzanych jest znacznie więcej danych osobowych niż ma to miejsce w sklepie stacjonarnym.

Bariery te wymuszają na klientach i przedsiębiorcach znajomości podstawowych aktów prawnych, które regulują zasady handlu w Internecie oraz związane z nimi obowiązki sprzedających i prawa kupujących.

\section{Bibliografia}

\section{Akty prawne}

Ogólne rozporządzenie o ochronie danych, Dziennik Urzędowy Unii Europejskiej L 119, 4 maja 2016. Ustawa o świadczeniu usług drogą elektroniczną, Dz.U. z 2002 r., nr 144, poz. 1204.

Ustawa z dnia 29 sierpnia 1997 r. o ochronie danych osobowych, Dz.U. z 1997 r., nr 133, poz. 883. Ustawa z dnia 2 marca 2000 r. o ochronie niektórych praw konsumentów oraz o odpowiedzialności za szkodę wyrządzoną przez produkt niebezpieczny, Dz.U. z 2000 r., nr 22, poz. 271.

\section{Opracowania}

Bartczak K., Bariery rozwojowe handlu elektronicznego, Exante, Wrocław 2016.

Begg D., Fisher S., Dornbush R., Mikroekonomia, PWE, Warszawa 2007.

Bramham J., Benchmarking w zarządzaniu zasobami ludzkimi, Oficyna Ekonomiczna, Kraków 2004.

Garrett G.A., Parrott G.A., E-Business - Understanding Key Trends and Applaying Best Practices, Contract Management 2005/7.

Gregor B., Kaczorowska-Spychalska D., Homo Cyber Oeconomicus - nowy wymiar zachowań konsumenckich, w: B. Gregor, D. Kaczorowska-Spychalska, Marketing w erze technologii cyfrowych, Wydawnictwo Naukowe PWN, Warszawa 2018.

Gregor B., Kalińska-Kula M., Rozwój handlu internetowego i jego uwarunkowania - perspektywa oferenta i nabywcy, Handel Wewnętrzny 2018/4 (375).

Krawczyk-Bryłka B., Hybrydowy model zaufania w Internecie, Zeszyty Naukowe Uniwersytetu Szczecińskiego 2009/541, Gdańsk.

Lew A., Oszustwa księgowe w obszarze przychodów i kosztów wpływajace na wiarygodny obraz jednostki gospodarczej wykrywane przez biegłego rewidenta, Prace Naukowe Uniwersytetu Ekonomicznego we Wrocławiu 2017/471, Wrocław.

Lewicki M., Instrumenty tworzenia wartości dla klienta $w$ handlu elektronicznym, http:// www.wbc.poznan.pl/Content/251091/M.Lewicki-Instrumenty_tworzenia_wartosci_dla_ klienta_w_handlu\%20elektronicznym.pdf; stan na 20.04.2019 r.

Mruk H., Marka w procesie kreowania wartości na rynku 4.0, w: B. Gregor, D. Kaczorowska-Spychalska, Marketing $w$ erze technologii cyfrowych, Wydawnictwo Naukowe PWN, Warszawa 2018.

Pawlikowska K., Poleszak M., Czujesz, czyli o komunikacji marketingowej i sprzedaży skierowanej do kobiet, CeDeWu.pl, Warszawa 2011.

Raport E-Commerce w Polsce. Gemius dla e-Commerce Polska. 
Skrzypek E., Jakość i efektywność, Wydawnictwo Uniwersytetu Marii Curie-Skłodowskiej, Lublin 2000, s. 84.

Szulc R., Kobylański A., E-biznes, Uniwersytet Warmińsko-Mazurski, Olsztyn 2014.

Tsai H., Huang H., Online Consumer Loyalty: Why E-Tailers Should seek a High-Profile Leadership Position, Computers in Human Behavior 2009/25.

Wawszczyk A., E-gospodarka. Poradnik przedsiębiorcy, Polska Agencja Rozwoju Przedsiębiorczości, Warszawa 2003.

Zieliński T., Zaufanie jako regulator decyzji ekonomicznych (analiza literatury), Management and Business Administration. Central Europe 2012/4.

\title{
Strony internetowe
}

https://ceo.com.pl/regulacje-prawne-handlu-sklepow-internetowych-prawa-e-konsumenta-33573; stan na 31.12.2019 r.

Poradnik E-commerce, Materiał przygotowany przez Grupę Roboczą E-commerce działającą w ramach IAB Polska, wersja elektroniczna: https://iab.org.pl/wp-content/uploads/2019/07/ Poradnik-E-Commerce-2019.pdf; stan na 4.01.2020 r.

\section{Dagmara SKURPEL}

\section{LEGAL REGULATIONS IN THE CONTEXT OF E-COMMERCE CUSTOMER SERVICE FROM THE PERSPECTIVE OF CONSUMERS AND MARKET ENTITIES}

\begin{abstract}
Background: Due to the dynamic development and characteristics of the e-commerce industry, an important element in its proper functioning are the legal regulations aimed at, on the one hand, enabling the proper functioning of entrepreneurs who conduct this type of business, and on the other, protecting the interests of the people who use the services of the e-commerce industry, in particular, consumers. This article presents the most important legal acts that regulate the functioning of online commerce and characterizes their most important provisions.

Research purpose: The purpose of this work was to examine whether online stores that operate in Poland respect the law. It also looked at how these provisions affect customer service.

Methods: The author conducted her own research both among e-shop customers and salesmen and employees of electronic stores. The survey was conducted in 2019 using an electronic questionnaire. The results were expanded to include the results of secondary research, thanks to which it was possible to compare customers' expectations regarding the level of service with the activities carried out by stores.

Conclusions: The analysis regarding the respect of legal provisions by e-stores and their implementation in everyday customer service showed that both the employees of online stores and the customers themselves are not fully aware of their rights and obligations. Online stores often do not place mandatory information on their pages, and they do not always know about the possibility of, e.g., returning the goods without giving a reason. Meanwhile, from the customer's point of view, information about the terms of complaints and returns, or e-shop address data, are the foundation for building the company's credibility.
\end{abstract}

Keywords: e-commerce, customer rights, legal aspects of e-commerce. 